\title{
Materials of the act character as sources on the category of missing persons and dead in the Great Patriotic War
}

\section{Aubakirova Assem Zhuniskhanovna}

Master of the Humanities, senior research officer of Research Center "Altaytanu" of East Kazakhstan State University. The Republic of Kazakhstan, 070002, Ust-Kamenogorsk, st. 30-Gv. divisions, 34. Email: aubakirova.a.j@bk.ru

Abstract. The collection consisting of orders of the Commissioner of Defence of the USSR during the Great Patriotic War and the military aspects connected with their everyday life is considered in the article. The contents of orders obviously illustrate shortcomings of the organizationquestions, granting resources and mobilization. Orders No. 46, 127, 166 explain a problem of inexplicable loss of human life which are still not found out. The fate of millions of people is still unknown because of unfair registration. From 307 orders included in the collection, 177 have been classified as "confidential", and 50 have been designated by a signature stamp of the increased privacy. Having studied orders, the maintenance of important questions has been opened. Difficulties of registration of those who have died in the Great Patriotic War and missing persons and also the questions connected with determination of category of the losses listed in orders.

Key words: The Great Patriotic War; deads; missing persons; act materials; source; everyday life of the military personnel.

\section{Ұлы Отан соғысында қаза тапқандар және хабарсыз кеткендер категориясына байланысты актілік сипаттағы материалдар дерек ретінде}

\section{Аубакирова Асем Жунисхановна}

гуманитарлық ғылымдар магистрі, С.Аманжолов атындағы Шығыс Қазақстан мемлекеттік университеті «Алтайтану» ҒЗО-ның аға ғылыми қызметкері. Қазақстан Республикасы, 070002, Өскемен қ, 30-Гв.дивизия к, 34. E-mail: aubakirova.a.j@bk.ru

Аңдатпа. Мақалада негізінен Ұлы Отан соғысы уақытында КСРО Қорғаныс Халық комиссарының бұйрықтарынан тұратын жинақтағы әскерилерге қатысты және олардың күнделікті өміріне қатысты аспектілер қарастырылған. Бұйрықтар мазмұны қаруландыру мен ұйымдастыру, ресурстармен қамтамасыз ету және мобилизация жұмыстарында орын алған кемшіліктерді айқын көрсетеді. № 46, 127, 166 бұйрықтар әлі күнге дейін реттелмей келе жатқан адам шығыны мәселесін түсіндіреді. Миллиондаған адамдардың тағдыры дұрыс жүргізілмеген тіркеу жұмыстарының салдарынан әлі күнге дейін белгісіз. Жинаққа енген 307 бұйрықтың 177-сіне «құпия», 50іне «аса құпия» белгісі соғылған. Бұйрықтарды толық қарастыра отырып, өзара байланысты маңызды сұрақтардың мазмұны ашылды. Ұлы Отан соғысында қаза тапқандар және хабарсыз кеткендерді тіркеуден өткізудің қиыншылықтары, шығын категориясын анықтауға байланысты сұрақтар бұйрықтарда көрсетілген.

Кілт сөздер: Ұлы Отан соғысы; қаза тапқандар; хабарсыз кеткендер; актілік материалдар; дерек; әскерилердің күнделікті өмірі.

\section{Материалы актового характера как источники по категории пропавших без вести и погибших в Великой Отечественной войне}

\section{Аубакирова Асем Жунисхановна}

магистр гуманитарных наук, старший научный сотрудник НИЦ «Алтайтану» ВосточноКазахстанского государственного университета имени С. Аманжолова. Республика Казахстан, 070002, г.Усть-Каменогорск, ул. 30-Гв.дивизии, 34. E-mail: aubakirova.a.j@bk.ru

Аннотация. В статье рассматривается сборник состоящий из приказов Комиссара Обороны СССР во время Великой Отечественной войны и военные аспекты связанные с их повседневной жизнью. Содержание приказов явно иллюстрирует недостатки в вопросах орга-низации, предоставлении ресурсов и мобилизации. Приказы № 46, 127, 166 объясняют проблему необъяснимых человеческих жертв которые до сих пор не выяснены. Судьба миллионов людей по-прежнему неизвестна из-за недобросовестной регистрации. Из 307 приказов, включенных в сборник, 177 были классифицированы как «секретные», а 50 были обозначены грифом повышенной секретности. Изучив приказы, было раскрыто содержание важных вопро-сов. 
Трудности регистрации тех, кто погиб в Великой Отечественной войне и пропавших без вести, а также вопросы, связанные с определением категории потерь, перечисленных в приказах.

Ключевые слова: Великая Отечественная война; погибшие; пропавшие без вести; актовые материалы; источник; повседеневность военнослужащих.

әОЖ/ Удк 94(574.42)

\title{
Ұлы Отан соғысында қаза тапқандар және хабарсыз кеткендер категориясына байланысты актілік сипаттағы материалдар дерек ретінде
}

\author{
Аубакирова А.Ж.
}

Елбасы Нұрсұлтан Назарбаевтың «Болашаққа бағдар: рухани жаңғыру» атты мақаласындағы халыққа Жолдауында Қазақстанның үшінші жаңғыруы басталғанын жария еткенін айтып өтті. Еліміз мықты, әрі жауапкершілігі жоғары біртұтас ұлт болу үшін болашаққа қалай қадам басу керек және бұқаралық сананы қалай өзгерту керектігі турасында елбасы: «Рухани жаңғыру - тарлан тарихтың, жасампаз бүгінгі күні мен жарқын болашақтың көкжиектерін үйлесімді сабақтастыратын ұлт жадының тұғырнамасы» деп анықтайды (Назарбаев 2017).

Жаңа заман ағымына төселе алатын қазақстандық бірегейлік пен өз тарихыңнын тамырын білу және есте сақтау маңызды мәселе екендігі айқындалып отыр.

Тарих парақтарында терең із қалдырған Ұлы Отан соғысы призмасы арқылы біздер және болашақ ұрпақ үшін тарихи жады мен тарихи амнезия арақатынасы өзекті мәселе болып табылады.

Бұл мәселе обьективті түрде Қазақстан Республикасының 1995 жылы қабылданған «Қазақстан Республикасындағы тарихи сананың қалыптасуы концепциясында» көрсетілген (Қазақстан Республикасындағы тарихи сананың қалыптасуы концепциясы1995).

Тарихи дереккөздерге табиғат тарихы мен адам қоғамына қатыстының бәрі жатқызылады.

Адам қоғамын зерттейтін тарих ғылымында дерек деп, адам қызметімен тығыз байланысты өткен өмірдің ескерткіштерін түсінеміз. Адамзаттың қоғамдық-тарихи қызметі процесінің нәтижесінде қоғамның қандайда бір тарихи кезеңде даму даму деңгейін көрсететін материалды және рухани құндылықтар жасалады.

Деректанулық әдебиеттерде А.В. Муравьевтың бөлуі бойынша екі түрлі жазу деректерінің тобы кездеседі: тарихи қалдықтар және тарихи дәстүрлер. Бірінші топқа актілік сипаттағы жазу деректері, яғни қоғамның қалыпты қызмет жасауын қамтамасыз ету үшін қажет болған заңнамалық нормалар қалыбындағы құжаттар жатқызылады (Игибаев 2013).

Соның ішінде бұйрық - бұлжытпай орындалатын ресми нұсқау. Ол белгілі бір адамдар тобына немесе белгілі бір тұлғаға қатысты болуы мүмкін Ұлы Отан соғысы мәселесі бойынша КСРО Қорғаныс бойынша Халық Комиссариатының бұйрықтары бірден бір шынайы ақпарат беретін дереккөзі болып табылады. Бұйрықтардың мәліметтерін пайдалану арқылы қаза тапқандар мен хабарсыз кеткендерді тіркеуден өткізудің салыстырмалы анализін жасауға мүмкіндік береді. Аталмыш бұйрықтар бүкіл Кеңес Одағын, соның ішінде Қазақстанды қамтиды. Сонымен қатар, бұл деректер бізге әскери өмірдің әлеуметтік сипаты туралы жеткілікті ақпарат береді. Соғыстың басын-дағы мәселелер - тасы- 
малдаудың қиыншылықтары, санитарлық-гигиеналық жағдай, азық-түлікпен қамтамасыз етілу, әскери киіммен қамтамасыз етілу туралы айтуға болады.

1997 жылы Ресей Федерациясының Қорғаныс Министрлігі Ресей Әскери тарихи институты 1941-1945 жылдардағы Ұлы Отан соғысы тарихы бойынша құжаттарды басып шығару бағдарламасының негізінде «Қорғаныс халық комиссарының бұйрықтары» құжаттар жинағын шығарды (Ресей Федерациясының Қорғаныс Министрлігі Ресей Әскери тарихи институты 1997).

Жинақ негізінен соғыс уақытында КСРО Қорғаныс Халық комиссарының бұйрықтарынан құралған. Бұйрықтарға көбінде И.В. Сталин өзі қол қойып отырған. Ол 1941 жылы 19 шілдеде қорғаныстың Халық комиссары, кейін осы жылы Бас Қолбасшы болған болатын. Сондықтан, осы аралықтағы бұйрықтар жоғары билік органдарының позициясын толығымен аша түседі. Құжатта бұйрықтар реті хронологиялық түрде басылған.

Бұйрықтар мазмұны қаруландыру мен ұйымдастыру жұмыстарында орын алған кемшіліктерді айқын көрсетеді. Мобилизация мәселесіне ерекше мән берілген. №46, 127, 166 бұйрықтар әлі күнге дейін реттелмей келе жатқан адам шығыны мәселесін түсіндіреді. 1941 жылғы № 46 және 1942 жылғы №166 бұйрықтар осы мәселенің шешімін таппағанын айғақтайды. Миллиондаған адамдардың тағдыры дұрыс жүргізілмеген тіркеу жұмыстарының салдарынан әлі күнге дейін белгісіз. Жинаққа енген 307 бұйрықтың 177-сіне «құпия», 50-іне «аса құпия» белгісі соғылған. Бұйрықтарды толық қарастыра отырып өзара байланысты маңызды сұрақтардың мазмұнын ашуға мүмкіндік бар.

1941 жылдың 15 наурызында КСРО Қорғаныс Халық комиссары, Кеңес Одағының маршалы С. Тимошенконың Қызыл Әскер қатарындағы дербес құрам шығынының есебі және оларды жерлеу туралы № 138 бұйрығын жарияланған болатын. Бұйрық 4 бөлімнен тұрды: бірінші бөлім - жалпы бөлім; екінші бөлім - Қызыл Әскер әскери бөлімдері, құрамалары мен мекемелеріндегі дербес құрамды тіркеу; үшінші бөлім - әскери қызметкерлер туралы дерек-тер мен медальондар тағайындау туралы; төртінші бөлім - Қызыл Әскерді жасақтау бойынша басқармадағы шығындарды тіркеу. Бұйрықтың екінші бөлімінде әрбір командир және басшы қоластындағы жеке құрамды қандай жағдай болмасын тіркеп отыруы қажет делінген. Дербес тіркеуге - жауынгердің қандай шайқаста және қай жерде қатысқаны, шайқаста өзін қалай көрсеткені туралы мәліметтер көрсетілуі қажет болған. Құжатсыз келген жауынгерлер ерекше тіркеуге алынып, жағдай анықталғанша осы тіркеуде болған.

Әскери қызметкерлер туралы деректер мен медальондар тағайындау туралы үшінші бөлімнің аталмыш бұйрыққа енуі 1939 жылғы № 238 (дербес медальондарды пайдалануды тоқтату туралы) бұйрықтың күшін жойды. Медальондар 2 данада жауынгер туралы толық мәлімет жазбасы салынған қара түсті бұрандалы пластик қорапшалар түрінде болды.

Дегенмен, 1942 жылы 17 қарашада №292 бұйрықпен Қорғаныс бойынша Халық Комиссарының 1941 жылғы №330 бұйрығының негізінде, жауынгер туралы барлық мәлімет жазылған қызыләскерші кітапшасының енгізілуіне байланысты осы мәліметтерді медальонға көшіріп салудың қажеттілігі болмай қалғандықтан, Қызыл Әскерді медальондармен жабдықтау тоқтатылды.

Қызыл Әскерді жасақтау бойынша басқармадағы шығындарды дербес тіркеуге қаза тапқандар, жарақаттан қайтыс болғандар, хабарсыз кеткендер, тұтқынға түскендер енді. Тіркеуді алфавит ретімен жүргізе отырып, жауынгерлердің туыстарына осы құжат негізінде анықтама беру жүктелді. 
1942 жылы әскердегі жеке құрам шығындарын есепке алу жұмыстарын жақсарту мақсатында жеке құрам шығындарын дербес есепке алу үшін Орталық Бюро құру туралы № 127 бұйрыққа қол қойылды.

Дегенмен, тіркеу жұмыстарының қажетті деңгейде жүргізілмей жатқандығын КСРО азаматтарының Орталық Комитетке жауынгер туыстарының тағдырына деген алаңдаушылық хаттарынан анық болды. Көптеген әскери бөлімдер жауынгерлердің туған-туыстарына бекітілген хабарламалар жібермей, Орталыққа уақытылы атаулы тізімдер жібермеу фактілері орын алған. Бұл жағдай халық жағынан сұрауларға егжей-тегжейлі жауап алмауынан әділ ескертулер туындауына себепкер болған. Оның үстіне отбасына асыраушысынан айрылу туралы зейнетақы тағайындатуды кешеуілдетеді. Әскери бөлімдердің уақытылы толыққанды тізімдер жібермеуі тіркеу жүргізуде мәліметтердің сәйкес келмеуін туындатқан. Осы себепті, 1942 жылдың 11 наурызында № 1424c бұйрығымен шайқаста қаза тапқан барлық жауынгерлер туралы хабарламаны туыстарына 15 күн ішінде жіберуге, ары қарай: қаза тапқандар туралы хабарламаны тізімнен алыну туралы бұйрық шығысымен; хабарсыз кеткендер мен тұтқынғы түскендер туралы хабарламаны жауын-герлердің туыстарына тізімнен алыну туралы бұйрық шыққаннан кейін 1 ай өткен соң жіберу міндеттелген.

Бұйрық осы сұрақ төңірегіндегі мәселені жоя алмағандығын 1942 жылғы 14 шілдедегі №224 бұйрығында анық болып отыр.

«1941 жылғы Қорғаныс бойынша Халық комиссарының № 138 бұйрығында берілген нұсқауларға қарамастан шайқастарда қаза тапқан жауынгерлердің отбасыларына жауынгердің өлімі туралы хабарлама қағазы үлкен мерзімде кешіктіріліп жатқан фрактілер орын алуда:

55-ші жаяу әскер батальонының комиссары Шелутко А.А. 1941 жылдың 3 қарашасында қаза тапқан, өлімі туралы хабарлама тек 1942 жылдың 5 сәуірінде жіберілген;

420-шы артиллериялық полктің лейтенанты Жавнирович П.3. 1941 жылдың 14 қыркүйегінде қаза тапқан, офицердің өлімі туралы хабарлама 6 айдан соң, яғни 1942 жылдың 23 наурызында ғана жіберілген;

150-ші танк бригадасының майоры Исакович И.Я. 1941 жылдың 24 шілдесінде қаза тапқан, қара қағаз отбасына 9 ай өткен соң, 1942 жылдың 19 сәуірінде жіберілген.

Кейбір қара қағаздарда хабарламаға қол қойылған күн көрсетілмеген, тіпті жауынгердің қаза тапқан күні жазылмаған жағдайлар кездескен».

Осы себептерге байланысты әскери бөлімдер мен құрамалардың командирлеріне жауынгердің қаза табу фактісін 2 күн ішінде анықтап, отбасына барлық талап етілген мәліметтермен толтырылған қара қағаз жіберу міндеттелген.

Ұлы Отан соғысы басталысымен Қызыл Әскер қатарына мобилизациялау жұмыстары басталып кетті. Соғысқа сұранып кетіп жатқан азаматтар қатары көп болды. Дегенмен, бұйрықтардың дерегінде адам факторымен орын алған қателіктерде болғандығы анықталып отыр.

«Әскери міндеттілерді тіркеу әскери комиссариаттардың жұмысы және оларды әскерге шақыру туралы» 1942 жылдың 14 сәуіріндегі № 170 бұйрық осы жылы наурызда жүргізілген облыстық, өлкелік, қалалық және аудандық әскери комиссариаттарды тексеру барысында қызметкерлердің әскери міндеттілерді тіркеу жұмысында асқан жауапкершіліксіз қателіктерге бой алдырғандығын анықтаған. 
1941 және 1942 жылдарда өткен әскери міндеттілерді қайта тіркеу жұмыстарында тіркеу жұмыстарындағы салмақты қателіктер туралы белгі берді. Қайта тіркеу кезінде әскери тіркеуде тұрған, бірақ шақыртудан қашып жүрген, әскери комиссариаттың жанында өмір сүріп жатқан ондаған мың адамдарды анықтаған.

Әскери құжаттарды тексеру кезінде әлі де осындай әскери міндеткерліктен қашқан адамдар табылған.

Әсіресе, әскерге шақыртудан босату ісінде көптеген басбұзарлықтар анықталған.

Әскери комиссариаттардың жалпы жұмысы төмендегідей сипатталып отыр:

1. Әскери міндеттілерді тіркеу шатасқан, дұрыс жүргізілмеуде. Әскери комиссариаттар әскери тіркеу столдарына шақырту нәтижесін жібермейді, сондықтан әскерге шақыртылғандар қолда бар ресурстар ретінде көрсетіледі. Оның үстіне әскер қатарында есепте тұрғандар өз үйлерінде тұрып жатқан болып шықты. Кейбір азаматтарда екі тіркеу карточкасы бар екендігі анықталған. Медициналық тексеру нәтижелері көп аудандарда карточкаға анық жазылмаған немесе мүлде жазылмаған. Аудандық әскери комиссариат басшылары, ауылдықты айтпағанда қаладағы әскери комиссариатқа барып тексеру жұмыстарын жүргізбейді.

2. Әскери тіркеу мамандықтарының шектен тыс көптігі тіркеу жұмыстарына шатаспақ әкеледі.

3. Әскери комиссариаттарға шақырту қағаз жүзінде ғана жүргізіледі. Шақырту қағаздарында "үйінде болған жоқ», «іссапарда» деген белгіні әскери міндеттінің туыстары келіп салып кетуіне жол берілген. Мұндай белгісі бар шақыртулар айлар бойы ұмыт қалдырылып, әскери міндеттілер әскерге шақыртылмай, тіркелмей қала береді. Әскери комиссариаттарға бармайтын тұлғаларға ешқандай жазалау шаралары қарастырылмаған.

4. Әскери міндеттілерді медициналық куәландыруда заңсыз шешімдер қабылданып, әскер қатарына жарайтын азаматтар денсаулық жағдайы бойынша әскерге жарамсыз деп танылып жатыр.

Кейбір аудандардағы денсаулық жағдайы бойынша әскерге жарамсыз деп танылған азаматтардың ішінде 15\%-дан 39\%-ға дейін қайта тіркеуден өткенде жарамды болып танылған. Сонымен қатар, денсаулығында кінәраты бар азаматтарды әскерге жарамды деп танып, құрамалар дайындау жұмысына кедергі келтіретіндер де өте көп.

5. Қышыма ауруларымен ауыратын азаматтардың жазылуы үшін ешқандай шаралар қабылданып жатқан жоқ.

6. Еңбекке жарамсыздық демалысындағы тұлғаларды тіркеу жолға қойылмаған.

7. Әскерге шақыртылмағандардың ішінде саяси-моральді «әкесі соттасқан», «ағасы репрессияланған», «екі рет соттасқан» деген себептермен азаматтар көптеп кездеседі.

8. Аудандық әскери комисариаттарда қабылданған нарядтармен дұрыс жұмыс жүргізілмейді.

9. Әскери столдарға әскери комитеттің қатынаспау себепті көптеген әскери комисариаттар адам ресурстарымен қамтамасыз ету мүмкін емес деген жауап жібереді.

10. Бұйрық уақытылы қызметкерлерге хабарланып, орындалмайды.

Әскери комиссариат ұйымдастыратын құжат тексеру шараларын көбінде біліксіз қызметкерлер жүргізеді. Бұл шаралар халық орналасқан барлық аймақтарды қамтымайды. Аудандық әскери комиссарлар теусеру жұмыстарын мили- 
ция органдарына сілтеп, өздері атқарудан қашады. Тексерушілер қандай құжаттардың заңды екендігін білмейді, білсе де әскери міндеттен қашқандарды ұстау мәселесін шешумен тоқтайды. Әскери міндеттілердің жол жүру ережелері дұрыс түсіндірілмеген.

11. Жергілікті өндіріс орындарына брондауда асыра сілтеу фрактілері орын алған. Әскери комиссариаттағы қызметкерлердің білмейтіндігін пайдаланып, аппарат және халық шаруашылығының жұмысшылары брондау кестесіне сай келмейтін мамандықтар бойынша көрсетілген.

12. Заңсыз облыстық және аудандық әскери комиссарлардың әскери міндеттілерді босату фрактілері орын алған.

Пара беру арқылы әскери міндеткерліктен құтылғандар бар. Барлық кінәлілер табылып, сот әділдігіне берілген.

13. Алмастырылмайтын мамандарды әскери комиссариаттар еш қиындықсыз әскерге шақыртып, майданға аттандырып жатыр. Ондай тізімге жоғары білікті зауыттар мен әскери өндіріс орындарындағы инженерлер, шеберлер, бригадирлер ілініп кеткен.

14. Әскери комиссариаттардың комиссарлары мен жетекшілері жеке азаматтардың арбауына түсіп, жетегінде кетуі нәтижесінде мемлекеттік міндеттер жеке тұлғалардың ықпалымен әскерге алынған.

15. Осы аталған тіркеуге алу кезіндегі, әскерге шақырту кезіндегі кемшіліктер осы саладағы мемлекетке қарсы элементтер мен алып - сатарлар ықпалында маңызды органдардың реттеусіз, басшылықсыз қалғандығын дәлелдеп отыр.

Әскери округ штабтары мен мобилизация және құрамаларды жабдықтаудың Бас басқармасы өздеріне бағынышты әскери комиссариаттардың қызметін бақылап, тексермейді.

Осы аталған кемшіліктердің барлығына нүкте қою үшін округтердің әскери кеңестеріне Бас кадр басқармасымен 1 ай көлемінде әскери комиссариаттардың жеке құрамын тексеру тапсырылып, әскерге жарайтындарының орнына әйелдер мен жеңіл жаралыларды тағайындау тапсырылған. Сонымен қатар, осы органдарға күнтәртібіндегі ең басты мәселе ретінде уақытылы жаңа құрамалармен қордағы бөлімшелерді толтыру тапсырылған.

Округтің әскери кеңестеріне:

1) инженерлік-техникалық мамандарды және жұмысшыларды әскери өндіріс орындарынан әскерге шақыртуға тыйым салынды;

2) брондаудың заңдылығын аудандық және облыстық әскери комиссариаттардың айына бір рет жіберілетін комиссиясымен арнайы тексеру.

Облыстық, өлкелік, республикалық, қалалық әскери комиссариаттарға қатысты шаралар осы бұйрық негізінде орындалған.

Ұлы Отан соғысы жылдарындағы адам ресурстарының шығынына енетін категориялар соғыс уақытында анықталған. 1944 жылы 4 ақпанда «Қызыл Әскердің жеке құрамын тіркеу бойынша түсіндірме (әскери уақыт)» №23 бұйрығы 1940 жылғы №450, 1941 жылғы №138 «Соғысушы әскер құрамындағы сандық құрам туралы хабарлама» бұйрығының 1944 жылдың 1 мамырынан бастап күшін жойды.

№23 бұйрықтың III тарауы соғысушы әскердегі қайтымсыз шығын құрамын анықтап берді: Қызыл Әскердің жеке құрамын тіркеу бойынша - қаза тапқандар, хабарсыз кеткендер, жарақаттан майдан алаңында және емдеу мекемелерінде қаза тапқандар, шайқасқа қатысу нәтижесінде аурудан қаза тапқандар, тұтқынға түскендерді әрбір дивизия штабы, корпус штабы, емдеу мекемелері, аудандық және қалалық әскери комиссариаттары, әскери бөлімдер, кадр- 
лар бөлімі, Қорғаныс бойынша Халық Комиссариатының кадрлар жөніндегі Бас басқармасы мекемелеріндегі жауапты тұлғалар нақты тіркеу есебін жүргізуге жауапты.

Осы бұйрықта тұтқынға түскен тұлғаларға дивизия шабына айына 2 рет атаулы тізім жіберу қажеттілігі көрсетілген (форма № 11 /БП). Дивизия шабында тізімдер тексеріліп, қайта тізім жасалып, шығындар есебі Басқармасына жіберіледі. Тұтқынға түскендерге толтырылатын формаға оның қамқорлығындағы отбасы мүшелері толығымен көрсетіледі.

Осы бұйрықта қаза тапқан жеке құрамды жерлеу тәртібі бойынша қаза тапқандар денесін майдан алаңынан алып шығу шайқастың қандайда жағдайында міндеттелген. Полк командирлері майдан алаңында қаза тапқандарды жерлейтін арнаулы жерлеу командасын құрап, командирлерін тағайындайды. Қаза тапқандарды жерлеу жеке немесе бауырластар моласына жерленеді. Жерлеу командасының жұмыс аймағына енетін басқа әскери құрамдардың да жауынгерлерін жерлеу командалары жерлеуге міндетті. Молалар үшін елді мекендердегі ең жақсы орындар таңдалып алынады: зираттар, саябақтар, бақтар, парктер, ал едімекендерден тыс жерлерде - қорғандар, алаңқайлар, жол торабы және т.б. Молалар үшін құрғақ, жер асты сулар төмен орналасқан орындар таңдалады. Молалар тереңдігі 1,5 метр, төмпешік биіктігі 0,5 метр деп белгіленген.

Жерлеу командасының басшысы қызыләскер кітапшасының, төлқұжаттың және т.б. құжаттар негізінде тізім жасап, жерлеу мәліметтері кітабына енгізеді. Қаза тапқан жауынгердің құжаттары болмаған жағдайда полк командирінің өкімімен бөлімше командирі қаза тапқан жауынгердің тұлғасын анықтайды. Қаза тапқан офрицерлік құрам жеке молаға жерленіп, топографиялық картаға жерленген орны белгіленеді.

«Майданда қаза тапқан әскери қызметкерлердің жеке заттарын жинау, тіркеу, жіберу, сақтау бойынша нұсқауына» сәйкес қаза тапқан жеке құрамның жеке заттары туысқандарына жіберіледі.

Тіркеу сипатындағы бұйрықтардан басқа әскери қызметкерлердің өмірінен тарихи ақпараттың маңызды дерегі ретінде әлеуметтік сипаттағы бұйрықтар қарастырылды.

1942 жылғы 21 ақпандағы «Әскери эшелондарды санитарлық-тұрмыстық қамтамасыз ету бойынша» № 133 бұйрығында майданға аттандырылып жатқан әскери эшелондарда адамдарға ыстық тамақ таратпай нәтижесінде адам өліміне әкелген жағдайлардың орын алғандығын атап көрсетеді. Сонымен қатар, кейбір эшелондарда адамдар аяқ киімсіз жүрген, көпшілігі жаздық киіммен аттанып кеткен және көптеген ауру адамдарға қажетті санитарлық көмек көрсетілмеген.

1942 жылы 16 шілдеде № 226 бұйрықпен Солтүстік-Кавказ фронтының азық-түлікпен қамтамасыз етуде жіберілген қателіктерді жою көзделген. Жауынгерлерге берілетін азық-түлік түрі қоймада жеткіліксіз мөлшерде болған. Кейбір батальондарда тамақ жасалатын азық-түлік жаыунгерлердің қолына дайын емес күйінде беріліп, жауынгерлер өздері тамақты кішкене ыдыстарда, консервінің бос қалбырларында, каскаларында дайындаған. Сонымен қатар, ас дайындауға арналған инвентарьлардың жоқтығы, жекелеген әскери бөлімдер белгіленген мөлшердегі азық-түлікті жауынгерлерге уақытылы бермейтіндігі анықталған.

Заттай қамтамасыз етуде жазғы және қысқы жауынгер мундирі қоймада артығымен болса да, жауынгерлерге берілмеген. Қоймада 86000 жұп аяқ киім болса да, жауынгерлер тозығы жеткен, жыртық аяқ киіммен жүрген. Орын алған 
жағдайларға жауапты тұлғалар және батальон комиссарлары әскери бөлімдерінде болып, тексеріс жүргізбегендіктен бұл жағдайдан бейхабар.

Мемлекеттік бақылау бойынша Халық комиссариатының тексерісі нәтижесінде Оңтүстік және Оңтүстік-Батыс фрронтта әскерге арналған халық жинаған мүліктің тоналғандығы анықталған.

Қамтамасыз ету бөлімінің жарғысымен сәлемдемелер мен сыйлықтар Қызыл Әскерге қатысы жоқ жеке тұлғаларға және ұйымдарға таратылған. 20 күн ішінде 2000 сәлемдеме таратылып кеткен. Ешқандай тіркеу және жауапкершілік жоқ. Азық-түлік және сыйлықтар, сәлемдемелер ауызша өкіммен және қолхаттармен өлшемсіз таратылған. Аталмыш фрактілерге байланысты әскерге арналған халық жинаған мүліктің тонауға жол берген тұлғаларды анықтап, жауапкершілікке тарту міндеттелген.

Қарастырылған бұйрықтар толығымен әскери уақытта орын алған жағдайларды баяндайды. Ұлы Отан соғысында қаза тапқандар және хабарсыз кеткендерді тіркеуден өткізудің қиыншылықтары, шығын категориясын анықтауға байланысты сұрақтар бұйрықтарда көрсетілген. Қаза тапқандарды жерлеу мәселесін толығымен нұсқаулық ретінде анықтап, жерлеу талаптарын айқындаған. Дерек ретінде пайдаланылған актілік сипаттағы материалдар қойылған сұрақтарды толықтай ашып көрсетті. Билік органдарының жіті бақылауында болды делінген әскери өмірдің әлеуметтік сипаты анықталды.

\section{Әдебиеттер тізімі/ Список литературы}

1. Игибаев С.К. История Казахстана в источниках и материалах. - Астана : Фолиант, 2013. - 320 с.

2. Қазақстан Республикасындағы тарихи сананың қалыптасуы концепциясы. - Алматы : Қазақстан, 1995. - 32 б.

3. Назарбаев Н.Ә. «Болашаққа бағдар: рухани жаңғыру» [Электронный ресурс]. // Егемен Қазақстан РГ, URL: www.egemen.kz/article/nursultan-nazarbaev-bolashaqqa-baghdar-rukhanizhanhghyru. (Дата обращения: 05.02.2018).

4. Ресей Федерациясының Қорғаныс Министрлігі Ресей Әскери тарихи институты. 1941-1945 жылдардағы Ұлы Отан соғысы тарихы бойынша құжаттарды басып шығару бағдарламасының негізінде «Қорғаныс халық комиссарының бұйрықтары» құжаттар жинағы. [Электронный ресурс] // Милетера. Военная литература, URL: www.militera.lib.ru. (Дата обращения: 05.02.2018).

\section{Reference}

Igibaev 2013 - Igibaev, SK, 2013, Istoriya Kazahstana v istochnikah i materialah, Foliant, Astana, 320 s. (Igibaev, SK, 2013, History of Kazakhstan in sources and materials, Foliant, Astana, 320 p.). (in Rus).

Kazakstan Respublikasyndagy tarihi 1995 - Kazakstan Respublikasyndagy tarihi sananyn kalyptasuy koncepciyasy, Kazakstan, Almaty, $32 \mathrm{~b}$. (The concept of formation of historical consciousness in the Republic of Kazakhstan, Kazakstan, Almaty, 32 p.). (in Kaz).

Nazarbaev 2017 - Nazarbaev, NA 2017, Bolashakka bagdar: ruhani zhangyru, Egemen Kazakstan $R G$, retrived 05 February 2018, www.egemen.kz. (Nazarbaev, NA 2017, The view in future: spiritual revival, Egemen Kazakstan RG, retrived 05 February 2018, www.egemen.kz). (in Kaz).

Resej Federaciyasynyn Korganys Nd - Resej Federaciyasynyn Korganys Ministrligi Resej Askeri tarihi instituty. 1941-1945 zhyldardagy Uly Otan sogysy tarihy bojynsha kuzhattardy basyp shygaru bagdarlamasynyn negizinde «Korganys halyk komissarynyn bujryktary» kuzhattar zhinagy, Militera. Military literature, retrived 05 February 2018, www.militera.lib.ru. (Russia Militaryhistorical Institute of the Ministry of defence of the Russian Federation. The publication of documents on the history of the great Patriotic war of 1941-1945, based on the program "orders of the people's Commissar of Defense" collection of documents, Militera. Military literature, retrived 05 February 2018, www.militera.lib.ru). (in Kaz). 